Article

\title{
Terminamines K-S, Antimetastatic Pregnane Alkaloids from the Whole Herb of Pachysandra terminalis
}

\author{
Xiang-Yu Li, Yang Yu, Miao Jia, Mei-Na Jin, Nan Qin, Chuan Zhao * and Hong-Quan Duan * \\ Tianjin Key Laboratory on Technologies Enabling Development Clinical Therapeutics and \\ Diagnostics (Theranostics), School of Pharmacy, Research Center of Basic Medical Sciences, \\ Tianjin Medical University, Tianjin 300070, China; lovelxybeibei@163.com (X.-Y.L.); yuyang@tmu.edu.cn (Y.Y.); \\ ijiamiao4ev@126.com (M.J.); jinmeina@tmu.edu.cn (M.-N.J.); nanqin.qn@163.com (N.Q.) \\ * Correspondence: zhaochuan@tmu.edu.cn (C.Z.); duanhq@tmu.edu.cn (H.-Q.D.); Tel.: +86-22-8333-6560 (C.Z.); \\ +86-22-8333-6680 (H.-Q.D.); Fax: +86-22-8333-6560 (C.Z. \& H.-Q.D.)
}

Academic Editor: Derek J. McPhee

Received: 11 August 2016; Accepted: 13 September 2016; Published: 26 September 2016

\begin{abstract}
Nine new pregnane alkaloids (1-9), together with eight known alkaloids (10-17), were isolated from the whole herb of Pachysandra terminalis. Their structures were elucidated on the basis of spectroscopic analyses. In addition, the isolates were examined for their ability to inhibit the migration of MDA-MB-231 cells induced by the chemokine epidermal growth factor (EGF). Alkaloids 1, 5, 7, 9, 12, and 17 presented significant anti-metastasis activities compared with the positive reagent, LY294002.
\end{abstract}

Keywords: Pachysandra terminalis; Buxaceae; pregnane alkaloids; anti-metastatic activity; structure-activity relationships

\section{Introduction}

Steroidal alkaloids are an important class of secondary metabolites that occur in plants and also in certain higher animals and marine invertebrates, and are the major constituents in plants of Apocynaceae, Buxaceae, Liliaceae, and Solanaceae [1,2]. Pachysandra terminalis Sieb. et Zucc. (Buxaceae) is distributed in the southwestern region of China and Japan. It has been used as a traditional medicine against pain and stomachache, with pregnane alkaloids as its main bioactive components [3]. Previous pharmacological research has shown that these compounds produce a wide range of pharmacological effects, such as antiulcer [4], cytotoxic [3], anti-leishmanial [5], anti-cancer [6], anti-breast cancer metastatic activities [7,8], as well as estrogen biosynthesis-promoting effects [9]. As part of an ongoing research program to identify bioactive steroidal alkaloids with anti-metastatic effects nine new (1-9) and eight known (10-17) pregnane alkaloids were isolated from the whole herb of Pachysandra terminalis. The isolation, structure elucidation, and anti-metastatic effects of these compounds are described, and their structure-activity relationships is discussed.

\section{Results and Discussion}

\subsection{Purification and Characterization}

The total alkaloid extract from the whole plants of $P$. terminalis was separated by silica gel column chromatography and semi-preparative reversed phase HPLC to yield nine new pregnane alkaloids, named terminamines K-S (1-9), and eight known alkaloids. By comparison of their spectroscopic data with values available in the literature, the known alkaloids were identified as: $(+)$-pachysandrine B (10) [10], epipachysandrine-A (11) [11], 3ß-methylamino 16-oxo 5,17(20) cis-pregnadiene (12) [12], 
Z-salignone (13) [13], terminamine H (14) [8], 3ß-methylamino 16-oxo 5,17(20) trans-pregnadiene (15) [12], E-salignone (16) [13], and (+)-spiropachysine (17) [14] (Figure 1). Structures of 1-9 were determined based on the 1D- and 2D-NMR, and mass spectrometric analytical results.

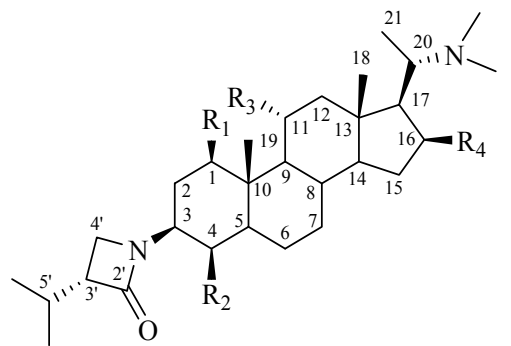

$$
\begin{array}{cccccc} 
& \mathrm{R}_{1} & \mathrm{R}_{2} & \mathrm{R}_{3} & \mathrm{R}_{4} & \\
1 & \text { OAc } & \text { OAc } & \text { ival } & \mathrm{OH} & \\
2 & \mathrm{H} & \text { oxo } & \mathrm{H} & \mathrm{H} & \Delta^{3^{\prime}, 5^{\prime}}
\end{array}
$$

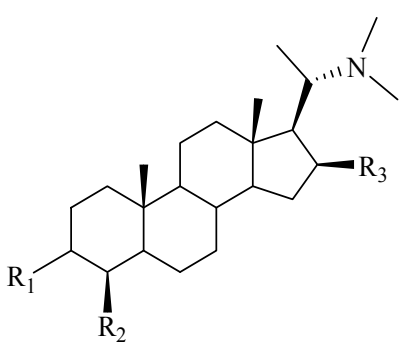

$\begin{array}{lll}\mathrm{R}_{1} & \mathrm{R}_{2} & \mathrm{R}_{3}\end{array}$

$7 \beta$-NH-sen $\mathrm{H} \quad \mathrm{OH} \quad \Delta^{5,6}$

$10 \alpha-\mathrm{N}(\mathrm{Me})-\operatorname{sen} \mathrm{OAc} \quad \mathrm{H}$<smiles>[R]C1C2CCC3C4CC[C@H]([C@H](C)N(C)C)[C@]4(C)CC[C@@H]3[C@]2(C)CC[C@H]1NC(=O)c1ccccc1</smiles>

$8 \alpha-\mathrm{OH}$

$11 \beta-\mathrm{OH}$<smiles>CNC(=O)c1ccccc1[C@@]12CCC1C1CCC3C(CC[C@]4(C)C3CC[C@@H]4C(C)N(C)C)[C@@]1(C)CC2</smiles>

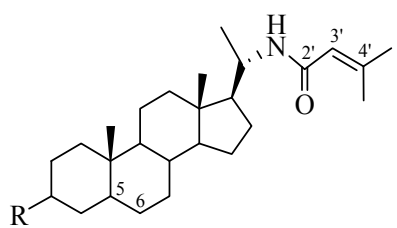

$\mathrm{R}$

$3 \quad \beta-\mathrm{N}(\mathrm{Me})_{2}$

$4 \beta-\mathrm{N}(\mathrm{Me})_{2} \Delta^{5,6}$

$5 \beta-\mathrm{NH}(\mathrm{Me}) \Delta^{5,6}$

$6 \alpha-\mathrm{NH}(\mathrm{Me}) \Delta^{5,6}$<smiles></smiles>

$9 \mathrm{Me} \Delta^{5,6}$

$12 \mathrm{H} \quad \Delta^{5,6}$

$13 \mathrm{Me}$<smiles>[R]N(C)[C@H]1CC[C@@]2(C)C(CC[C@H]3C4CC(=O)/C(=C/C)[C@@]4(C)CC[C@H]32)C1</smiles>

$\mathrm{R}$

$\begin{array}{lcc}14 & \mathrm{Me} & \Delta^{5,6} \\ 15 & \mathrm{H} & \Delta^{5,6} \\ 16 & \mathrm{Me} & \end{array}$

ival=isovaleryl= ${ }^{2} s_{2}$

sen=senecioyl=

Figure 1. Structures of compounds 1-17.

\subsection{Structural Elucidation of Compounds 1-9}

Alkaloid 1 was obtained as a yellow oil and its molecular formula was established as $\mathrm{C}_{38} \mathrm{H}_{62} \mathrm{~N}_{2} \mathrm{O}_{8}$ on the basis of the positive-ion mode HRESIMS data $\left(\mathrm{m} / \mathrm{z} 675.4617[\mathrm{M}+\mathrm{H}]^{+}\right.$, calcd for $\mathrm{C}_{38} \mathrm{H}_{63} \mathrm{~N}_{2} \mathrm{O}_{8}$, 675.4584). The IR spectrum displayed absorption bands at 3362 and $1750 \mathrm{~cm}^{-1}$, accounting for the 
presence of hydroxyl and carbonyl groups. The ${ }^{1} \mathrm{H}-\mathrm{NMR}$ spectrum of $\mathbf{1}$ revealed four oxygenated protons $\left[\delta_{\mathrm{H}} 5.05(1 \mathrm{H}, \mathrm{m}), 4.95(1 \mathrm{H}, \mathrm{dd}, J=11.2,4.8 \mathrm{~Hz}), 4.55(1 \mathrm{H}, \mathrm{dd}, J=12.0,4.0 \mathrm{~Hz}), 4.33(1 \mathrm{H}, \mathrm{m})\right]$, four tertiary methyls $\left[\delta_{\mathrm{H}} 2.05,1.94,1.15,0.86\right.$ (each $\left.\left.3 \mathrm{H}, \mathrm{s}\right)\right]$, five secondary methyls $\left[\delta_{\mathrm{H}} 1.03\right.$, 1.07 (each $3 \mathrm{H}, \mathrm{d}, J=6.7 \mathrm{~Hz}) ; 0.89,1.04($ each $3 \mathrm{H}, \mathrm{d}, J=7.6 \mathrm{~Hz}) ; 0.89(3 \mathrm{H}, \mathrm{d}, J=6.4 \mathrm{~Hz})]$, and six $\mathrm{N}_{\left(\mathrm{CH}_{3}\right)_{2}}$ protons $\left[\delta_{\mathrm{H}} 2.23(6 \mathrm{H}, \mathrm{s})\right]$. The ${ }^{1} \mathrm{H}-\mathrm{NMR}$ spectrum supported a steroidal skeleton in $\mathbf{1}$, with two methyl singlets resonating upfield at $\delta_{\mathrm{H}} 0.86$ and 1.15 , characteristic of C-18 and C-19 methyls, respectively [15].

In combination with analysis of the ${ }^{1} \mathrm{H}-{ }^{1} \mathrm{H}$ COSY, HSQC, and HMBC spectra, an isopropyl lactam group $\left(\delta_{C} 170.1,56.2,45.4,27.5,19.8,19.7\right)$, one isovaleryl group $\left(\delta_{C} 176.3,26.5,40.2,14.1,10.8\right)$, together with two acetyl groups $\left(\delta_{C} 170.8 \times 2,21.9,21.0\right)$ were identified. The remaining 21 carbon signals were assigned to the pregnane skeleton, similar to those of terminamine C [7]. By comparison of the NMR spectroscopic data with 10, 1 was proposed to have an acetyl group at the C-4 position, instead of a hydroxyl group. In the HMBC spectrum, correlations were observed for the resonance at $\delta_{\mathrm{H}} 4.55(\mathrm{H}-4)$ with the signals at $\delta_{\mathrm{C}} 170.8$ (acetyl group), 48.0 (C-3), $44.2(\mathrm{C}-5)$, and 22.9 (C-6). Thus, the acetyl group was assigned at C-4 (Figure 2).

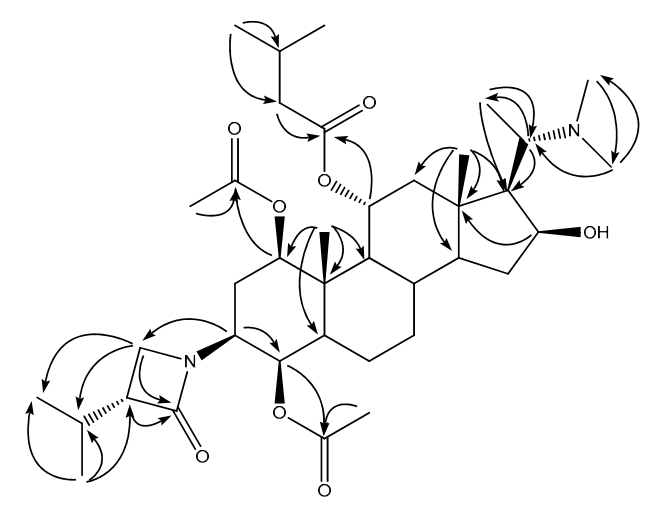

Figure 2. Key $\mathrm{HMBC}(\mathrm{H} \rightarrow \mathrm{C})$ correlations for $\mathbf{1}$.

In the ROESY spectrum, the proton signal of H-5 (1.70) correlated with H-1 (4.95), H-3 (4.18), and H-4 (4.55); the signal H-16 (4.33) correlated with H-14 (0.99) and H-17 (1.21); H-11 (5.05) with H-19 (1.15); and H-20 (2.89) with H-18 (0.86). The above observations indicated $\alpha$-orientations for $\mathrm{H}-1, \mathrm{H}-3, \mathrm{H}-4, \mathrm{H}-16$, and $\mathrm{H}-17$, and a $\beta$-orientation for $\mathrm{H}-11$ (Figure 3). The above $3^{\prime} \alpha$-isopropyl)-lactam-11 $\alpha$-ival-5 $\alpha$-pregnane, and named terminamine $\mathrm{K}$ (Figure 1 ).

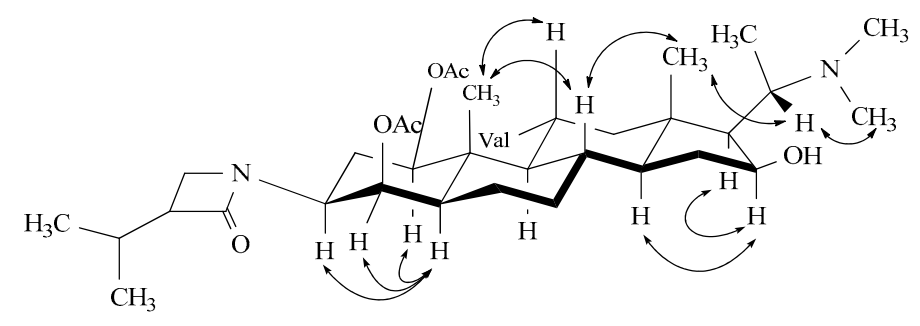

Figure 3. Key NOEs for $\mathbf{1}$.

Terminamine L (2) was isolated as a white powder, the HRESIMS showed a molecular ion peak at $m / z 455.3631\left([\mathrm{M}+\mathrm{H}]^{+}\right.$, calcd for $\left.\mathrm{C}_{29} \mathrm{H}_{47} \mathrm{~N}_{2} \mathrm{O}_{2}, 455.3638\right)$. The ${ }^{1} \mathrm{H}-\mathrm{NMR}$ spectrum of 2 featured four tertiary methyl signals at $\delta_{\mathrm{H}} 2.04,1.70,0.75$, and 0.65 (each $3 \mathrm{H}, \mathrm{s}$ ), a secondary methyl at $\delta_{\mathrm{H}}$ $0.90(3 \mathrm{H}, \mathrm{d}, J=6.4 \mathrm{~Hz})$, and six $\mathrm{N}\left(\mathrm{CH}_{3}\right)_{2}$ protons at $\delta_{\mathrm{H}} 2.21(6 \mathrm{H}, \mathrm{s})$. The ${ }^{13} \mathrm{C}-\mathrm{NMR}$ spectroscopic data for 2 were similar to those of terminamine E [7], except for the signals of C-4 (Table 1), and 2 was deduced to be the 4-oxo derivative of terminamine E. In the HMBC spectrum, two methyl groups $\left(\delta_{\mathrm{H}} 2.04\right.$ and 1.70) showed a correlation with double bond carbons $\left(\delta_{\mathrm{C}} 130.9\right.$ and 135.1), while the 
proton signals at $\delta_{\mathrm{H}} 3.93$ and $3.68\left(\mathrm{H}-4^{\prime}\right)$ showed correlations with $\delta_{\mathrm{C}} 130.9(\mathrm{C}=\mathrm{C})$ and $\delta_{\mathrm{C}} 165.1(\mathrm{C}=\mathrm{O})$, suggesting a $3^{\prime}$-isopropylidene lactam. On the other hand, the proton signals at $\delta_{\mathrm{H}} 4.42(\mathrm{H}-3)$ correlated with signals at $\delta_{C} 27.6(C-2), 207.6(C-4), 45.8$, and 165.1 ( $\beta$-lactam moiety). Thus, the $\beta$-lactam and ketone groups were assigned to $\mathrm{C}-3$ and $\mathrm{C}-4$, respectively. Finally, all of the available data identified the structure of 2 as $20 \alpha$-dimethylamino-3 $\beta$-( $3^{\prime}$-isopropylidene)-lactam- $5 \alpha$-pregn-4-one (Figure 1 ).

Table 1. NMR Spectroscopic data (400 MHz, $\left.\mathrm{CDCl}_{3}\right)$ for Terminamine $\mathrm{K}$ (1) and Terminamine L (2).

\begin{tabular}{|c|c|c|c|c|}
\hline \multirow{2}{*}{ Position } & \multicolumn{2}{|c|}{ Terminamine K (1) } & \multicolumn{2}{|c|}{ Terminamine L (2) } \\
\hline & $\delta_{C}$ & $\delta_{H}(J$ in $\mathrm{Hz})$ & $\delta_{C}$ & $\delta_{\mathrm{H}}(J$ in $\mathrm{Hz})$ \\
\hline \multirow[t]{2}{*}{1} & 74.6 & 4.95, dd $(11.2,4.8)$ & 36.5 & $1.96, \mathrm{~m}$ \\
\hline & & & & $1.54, \mathrm{~m}$ \\
\hline \multirow[t]{2}{*}{2} & 28.1 & $1.70, \mathrm{~m}$ & 27.6 & $1.93, \mathrm{~m}$ \\
\hline & & $2.33, \mathrm{~m}$ & & $1.55, \mathrm{~m}$ \\
\hline 3 & 48.0 & $4.18, \mathrm{~m}$ & 58.5 & $4.42, \mathrm{~m}$ \\
\hline 4 & 72.2 & $4.55, \mathrm{dd}(12.0,4.0)$ & 207.6 & - \\
\hline 5 & 44.2 & $1.70, \mathrm{~m}$ & 58.2 & $2.16, \mathrm{~m}$ \\
\hline \multirow[t]{2}{*}{6} & 22.9 & $1.33, \mathrm{~m}$ & 20.3 & $1.62, \mathrm{~m}$ \\
\hline & & $1.82, \mathrm{~m}$ & & $1.44, \mathrm{~m}$ \\
\hline \multirow[t]{2}{*}{7} & 32.1 & $1.00, \mathrm{~m}$ & 30.2 & $1.75, \mathrm{~m}$ \\
\hline & & $1.88, \mathrm{~m}$ & & $0.81, \mathrm{~m}$ \\
\hline 8 & 34.1 & $1.69, \mathrm{~m}$ & 34.9 & $1.30, \mathrm{~m}$ \\
\hline 9 & 56.6 & $1.41, \mathrm{~m}$ & 54.2 & $0.96, \mathrm{~m}$ \\
\hline 10 & 42.2 & - & 42.5 & - \\
\hline \multirow[t]{2}{*}{11} & 71.4 & $5.05, \mathrm{~m}$ & 21.6 & $1.55, \mathrm{~m}$ \\
\hline & & & & $1.26, \mathrm{~m}$ \\
\hline \multirow[t]{2}{*}{12} & 45.0 & $2.60, \mathrm{~m}$ & 39.6 & $1.91, \mathrm{~m}$ \\
\hline & & $0.80, \mathrm{~m}$ & & $1.20, \mathrm{~m}$ \\
\hline 13 & 41.2 & & 41.7 & \\
\hline 14 & 51.4 & $0.99, \mathrm{~m}$ & 54.7 & $1.40, \mathrm{~m}$ \\
\hline \multirow{2}{*}{15} & 35.1 & $2.21, \mathrm{~m}$ & 24.0 & $1.62, \mathrm{~m}$ \\
\hline & & $1.19, \mathrm{~m}$ & & $1.08, \mathrm{~m}$ \\
\hline 16 & 72.5 & $4.33, \mathrm{~m}$ & 27.5 & $1.92, \mathrm{~m}$ \\
\hline 17 & 58.8 & $1.21, \mathrm{~m}$ & 56.1 & $1.09, \mathrm{~m}$ \\
\hline 18 & 14.4 & $0.86, \mathrm{~s}$ & 12.3 & $0.65, \mathrm{~s}$ \\
\hline 19 & 10.6 & $1.15, \mathrm{~s}$ & 13.8 & $0.75, \mathrm{~s}$ \\
\hline 20 & 56.6 & $2.89, \mathrm{~m}$ & 61.3 & $2.54, \mathrm{~m}$ \\
\hline 21 & 9.8 & $0.89, \mathrm{~d}(6.4)$ & 10.0 & $0.90, \mathrm{~d}(6.4)$ \\
\hline $\mathrm{N}(\mathrm{Me})_{2}$ & 39.8 & $2.23, \mathrm{~s}$ & 39.9 & $2.21, \mathrm{~s}$ \\
\hline $2^{\prime}$ & 170.1 & - & 165.1 & - \\
\hline $3^{\prime}$ & 56.2 & $3.06, \mathrm{~m}$ & 130.9 & - \\
\hline \multirow[t]{2}{*}{$4^{\prime}$} & 45.4 & $3.70, \mathrm{~m}$ & 45.8 & $3.93, \mathrm{~d}(6.5)$ \\
\hline & & $3.18, \mathrm{~m}$ & & $3.68, \mathrm{~d}(6.5)$ \\
\hline $5^{\prime}$ & 27.5 & $2.06, \mathrm{~m}$ & 135.1 & - \\
\hline \multirow[t]{2}{*}{$5^{\prime}-(\mathrm{Me})_{2}$} & 19.8 & $1.03, \mathrm{~d}(6.7)$ & 19.9 & $2.04, \mathrm{~s}$ \\
\hline & 19.7 & $1.07, \mathrm{~d}(6.7)$ & 20.3 & $1.70, \mathrm{~s}$ \\
\hline \multirow[t]{2}{*}{ 1-OAc } & 21.9 & $1.94, \mathrm{~s}$ & & \\
\hline & 170.8 & & & \\
\hline \multirow[t]{2}{*}{ 4-OAc } & 21.0 & $2.05, \mathrm{~s}$ & & \\
\hline & 170.8 & & & \\
\hline \multirow[t]{6}{*}{ 11-Val } & 176.3 & & & \\
\hline & 26.5 & $1.43, \mathrm{~m}$ & & \\
\hline & & $1.65, \mathrm{~m}$ & & \\
\hline & 40.2 & $2.31, \mathrm{~m}$ & & \\
\hline & 14.1 & $1.04, \mathrm{~d}(7.6)$ & & \\
\hline & 10.8 & $0.89, \mathrm{~d}(7.6)$ & & \\
\hline
\end{tabular}


Terminamine $\mathrm{M}$ (3) was obtained as a white powder and assigned the molecular formula $\mathrm{C}_{28} \mathrm{H}_{48} \mathrm{~N}_{2} \mathrm{O}$ from its HRESIMS. The ${ }^{1} \mathrm{H}-\mathrm{NMR}$ spectrum of 3 revealed the presence of two proton signals $\left[\delta_{\mathrm{H}} 5.12(1 \mathrm{H}, \mathrm{d}, J=9.1 \mathrm{~Hz}), 4.05(1 \mathrm{H}, \mathrm{m})\right]$ connected with electron-withdrawing groups, an olefinic proton $\left[\delta_{\mathrm{H}} 5.49(1 \mathrm{H}, \mathrm{s})\right]$, four tertiary methyls $\left[\delta_{\mathrm{H}} 2.13,1.82,0.77\right.$, and $0.72($ each $\left.3 \mathrm{H}, \mathrm{s})\right]$, a secondary methyl $\left[\delta_{\mathrm{H}} 1.16(3 \mathrm{H}, \mathrm{d}, J=6.3 \mathrm{~Hz})\right]$, and two $\mathrm{NCH}_{3}$ methyls $\left[\delta_{\mathrm{H}} 2.36(6 \mathrm{H}, \mathrm{s})\right]$.

The ${ }^{13} \mathrm{C}$-NMR and DEPT spectra of 3 indicated the presence of seven methyls $\left(\delta_{C} 41.3,41.3\right.$, $27.1,21.9,19.7,12.4,12.3)$, a double bond $\left(\delta_{C} 150.0,119.0\right)$, and one ketone carbonyl $\left(\delta_{C} 165.8\right)$. In addition, nine methylenes, seven methines, and two quaternary carbons were also observed. Analysis of the ${ }^{1} \mathrm{H}$ - and ${ }^{13} \mathrm{C}-\mathrm{NMR}$ data supported a pregnane skeleton in 3 (Table 2), and resembled those of epipachysamine $\mathrm{E}[7,10]$. However, the signals of the related positions of $N, N$-dimethyl and senecioylamino groups $\left\{\delta_{\mathrm{H}} 2.47(\mathrm{H}-3), 4.05(\mathrm{H}-20), 2.36\left[\mathrm{H}-\mathrm{N}(\mathrm{Me})_{2}\right] ; \delta_{\mathrm{C}} 64.4(\mathrm{C}-3), 47.2(\mathrm{C}-20)\right.$, $\left.41.3\left[\mathrm{C}-\mathrm{N}(\mathrm{Me})_{2}\right]\right\}$ in 3 showed a significant difference with those of epipachysamine $\mathrm{E}\left\{\delta_{\mathrm{H}} 3.42(\mathrm{H}-3)\right.$, 3.79 (H-20), 2.17 [H-N(Me) $\left.{ }_{2}\right]$; $\delta_{\mathrm{C}} 61.1$ (C-3), 48.5 (C-20), 35.5 [C-N(Me) $\left.)_{2}\right]$.

Table 2. NMR Spectroscopic data (400 MHz, $\left.\mathrm{CDCl}_{3}\right)$ for Terminamine M-P (3-6).

\begin{tabular}{|c|c|c|c|c|c|c|c|c|}
\hline \multirow{2}{*}{ Position } & \multicolumn{2}{|c|}{ Terminamine M (3) } & \multicolumn{2}{|c|}{ Terminamine N (4) } & \multicolumn{2}{|c|}{ Terminamine $\mathrm{O}(5)$} & \multicolumn{2}{|c|}{ Terminamine $\mathbf{P}$ (6) } \\
\hline & $\delta_{C}$ & $\delta_{H}(J$ in $\mathrm{Hz})$ & $\delta_{C}$ & $\delta_{\mathrm{H}}(J$ in $\mathrm{Hz})$ & $\delta_{C}$ & $\delta_{\mathrm{H}}(J$ in $\mathrm{Hz})$ & $\delta_{C}$ & $\delta_{\mathrm{H}}(J$ in $\mathrm{Hz})$ \\
\hline \multirow[t]{2}{*}{1} & 37.6 & $1.79, \mathrm{~m}$ & 38.3 & $1.90, \mathrm{~m}$ & 37.6 & $1.90, \mathrm{~m}$ & 33.3 & $1.30, \mathrm{~m}$ \\
\hline & & $0.96, \mathrm{~m}$ & & $1.06, \mathrm{~m}$ & & $1.06, \mathrm{~m}$ & & $1.60, \mathrm{~m}$ \\
\hline \multirow[t]{2}{*}{2} & 24.0 & $1.57, \mathrm{~m}$ & 24.0 & $1.60, \mathrm{~m}$ & 24.0 & $1.60, \mathrm{~m}$ & 25.0 & $1.74, \mathrm{~m}$ \\
\hline & & $1.09, \mathrm{~m}$ & & $1.13, \mathrm{~m}$ & & $1.11, \mathrm{~m}$ & & \\
\hline 3 & 64.4 & $2.47, \mathrm{~m}$ & 64.9 & $2.23, \mathrm{~m}$ & 59.5 & $2.59, \mathrm{~m}$ & 54.9 & $2.81, \mathrm{~m}$ \\
\hline \multirow[t]{2}{*}{4} & 32.0 & $0.87, \mathrm{~m}$ & 35.2 & $2.24, \mathrm{~m}$ & 37.3 & $2.35, \mathrm{~m}$ & 36.4 & $2.48, \mathrm{~m}$ \\
\hline & & $1.67, \mathrm{~m}$ & & & & & & $2.12, \mathrm{~m}$ \\
\hline 5 & 45.6 & $1.09, \mathrm{~m}$ & 142.0 & - & 140.0 & - & 139.0 & - \\
\hline \multirow[t]{2}{*}{6} & 30.5 & $1.55, \mathrm{~m}$ & 120.7 & $5.35, \mathrm{~m}$ & 121.9 & $5.37, \mathrm{~m}$ & 122.9 & $5.35, \mathrm{~m}$ \\
\hline & & $1.32, \mathrm{~m}$ & & & & & & \\
\hline \multirow[t]{2}{*}{7} & 28.9 & $1.28, \mathrm{~m}$ & 31.9 & $1.99, \mathrm{~m}$ & 31.8 & $1.99, \mathrm{~m}$ & 31.8 & $1.95, \mathrm{~m}$ \\
\hline & & & & $1.53, \mathrm{~m}$ & & $1.50, \mathrm{~m}$ & & $1.58, \mathrm{~m}$ \\
\hline 8 & 35.3 & $1.37, \mathrm{~m}$ & 31.7 & $1.49, \mathrm{~m}$ & 31.7 & $1.47, \mathrm{~m}$ & 31.7 & $1.47, \mathrm{~m}$ \\
\hline 9 & 54.3 & $0.64, \mathrm{~m}$ & 50.2 & $0.95, \mathrm{~m}$ & 50.1 & $0.95, \mathrm{~m}$ & 50.0 & $1.09, \mathrm{~m}$ \\
\hline 10 & 35.7 & - & 36.9 & - & 37.0 & - & 37.2 & - \\
\hline \multirow[t]{2}{*}{11} & 21.0 & $1.51, \mathrm{~m}$ & 20.8 & $1.49, \mathrm{~m}$ & 20.8 & $1.48, \mathrm{~m}$ & 20.6 & $1.48, \mathrm{~m}$ \\
\hline & & $1.27, \mathrm{~m}$ & & & & & & \\
\hline \multirow[t]{2}{*}{12} & 39.4 & $1.91, \mathrm{~m}$ & 39.2 & $1.96, \mathrm{~m}$ & 39.1 & $1.95, \mathrm{~m}$ & 39.1 & $1.94, \mathrm{~m}$ \\
\hline & & $1.11, \mathrm{~m}$ & & $1.16, \mathrm{~m}$ & & $1.17, \mathrm{~m}$ & & $1.16, \mathrm{~m}$ \\
\hline 13 & 42.2 & - & 41.9 & - & 41.9 & - & 41.9 & - \\
\hline 14 & 56.6 & $1.02, \mathrm{~m}$ & 56.8 & $1.07, \mathrm{~m}$ & 56.8 & $1.03, \mathrm{~m}$ & 56.7 & $1.05, \mathrm{~m}$ \\
\hline \multirow[t]{2}{*}{15} & 24.1 & $1.82, \mathrm{~m}$ & 25.0 & $1.81, \mathrm{~m}$ & 24.0 & $1.59, \mathrm{~m}$ & 24.0 & $1.59, \mathrm{~m}$ \\
\hline & & $1.47, \mathrm{~m}$ & & $1.50, \mathrm{~m}$ & & $1.11, \mathrm{~m}$ & & $1.10, \mathrm{~m}$ \\
\hline \multirow[t]{2}{*}{16} & 26.8 & $1.75, \mathrm{~m}$ & 26.8 & $1.78, \mathrm{~m}$ & 26.7 & $1.77, \mathrm{~m}$ & 26.8 & $1.77, \mathrm{~m}$ \\
\hline & & $1.46, \mathrm{~m}$ & & $1.49, \mathrm{~m}$ & & $1.49, \mathrm{~m}$ & & $1.47, \mathrm{~m}$ \\
\hline 17 & 56.9 & $1.28, \mathrm{~m}$ & 56.9 & $1.31, \mathrm{~m}$ & 56.8 & $1.31, \mathrm{~m}$ & 56.7 & $1.31, \mathrm{~m}$ \\
\hline 18 & 12.3 & $0.72, \mathrm{~s}$ & 12.2 & $0.75, \mathrm{~s}$ & 12.2 & $0.75, \mathrm{~s}$ & 12.1 & $0.75, \mathrm{~s}$ \\
\hline 19 & 12.4 & $0.77, \mathrm{~s}$ & 19.4 & $0.98, \mathrm{~s}$ & 19.3 & $1.00, \mathrm{~s}$ & 19.1 & $1.02, \mathrm{~s}$ \\
\hline 20 & 47.2 & $4.05, \mathrm{~m}$ & 47.2 & 4.06, m & 47.2 & $4.05, \mathrm{~m}$ & 47.2 & $4.05, \mathrm{~m}$ \\
\hline 21 & 21.9 & $1.16, \mathrm{~d}(6.3)$ & 21.9 & $1.17, \mathrm{~d}(6.8)$ & 21.9 & $1.17, \mathrm{~d}(6.4)$ & 21.9 & $1.17, \mathrm{~d}(6.5)$ \\
\hline $\mathrm{N}(\mathrm{Me})_{2}$ & 41.3 & $2.36, \mathrm{~s}$ & 41.6 & $2.35, \mathrm{~s}$ & 31.7 & $2.49, \mathrm{~s}$ & 33.1 & $2.38, \mathrm{~s}$ \\
\hline $\mathrm{NH}$ & - & $5.12, \mathrm{~d}(9.1)$ & - & $5.13, \mathrm{~d}(8.8)$ & - & $5.13, \mathrm{~d}(8.8)$ & - & $5.21, \mathrm{~d}(8.1)$ \\
\hline $2^{\prime}$ & 165.8 & - & 165.8 & - & 165.8 & - & 165.8 & - \\
\hline $3^{\prime}$ & 119.0 & $5.49, \mathrm{~s}$ & 119.0 & $5.49, \mathrm{~s}$ & 119.0 & $5.49, \mathrm{~s}$ & 119.1 & $5.50, \mathrm{~s}$ \\
\hline $4^{\prime}$ & 150.0 & - & 150.0 & - & 150.0 & - & 149.9 & - \\
\hline \multirow[t]{2}{*}{$4^{\prime}-(\mathrm{Me})_{2}$} & 19.7 & $2.13, \mathrm{~s}$ & 19.7 & $2.14, \mathrm{~s}$ & 19.7 & $2.14, \mathrm{~s}$ & 19.7 & $2.14, \mathrm{~s}$ \\
\hline & 27.1 & $1.82, \mathrm{~s}$ & 27.1 & $1.82, \mathrm{~s}$ & 27.1 & $1.82, \mathrm{~s}$ & 27.1 & $1.82, \mathrm{~s}$ \\
\hline
\end{tabular}

In the HMBC spectrum, the methyl proton signals at $\delta_{\mathrm{H}} 2.36\left(\mathrm{NMe}_{2}\right)$ correlated with the carbon signal at $\delta_{\mathrm{C}} 64.4(\mathrm{C}-3)$, suggesting the $N, N$-dimethyl group was located at $\mathrm{C}-3$. On the other hand, the proton signal at $\delta_{\mathrm{H}} 4.05(\mathrm{H}-20)$ correlated with the proton signal at $\delta_{\mathrm{H}} 5.12(\mathrm{H}-\mathrm{NH})$ in the 
COSY spectrum, while the proton signal at $\delta_{\mathrm{H}} 5.12(\mathrm{H}-\mathrm{NH})$ correlated with the proton signals at $\delta_{\mathrm{H}} 5.49\left(\mathrm{H}-3^{\prime}\right)$ and $1.16(\mathrm{H}-21)$ in the ROESY spectrum, which indicated that the senecioylamino group was assigned to position C-20. Furthermore, the ROESY correlations between $\mathrm{H}-18\left(\delta_{\mathrm{H}} 0.72\right)$ and $\mathrm{H}-20\left(\delta_{\mathrm{H}} 4.05\right)$ indicated a $\beta$-orientation for $\mathrm{H}-17$. However, there was no further chemical or spectral evidence for the identification of the relative configuration for C-3, except for the 1D-NMR data $[8,13]$. A series of 3-isomers of pregnane alkaloid derivatives were synthesized using the stereoselective Mitsunobu reaction [16] by this group [17-19]. The results suggested that the C-3 signal of $3 \beta$-dimethylamino derivatives appeared more downfield. The carbon signal at $\delta_{C} 64.4(C-3)$ was in correspondence to that of the $3 \beta$-dimethylamino derivatives. Thus, the structure of 3 was assigned as $3 \beta$-dimethylamino- $20 \alpha$-senecioylamino- $5 \alpha$-pregnane (Figure 1 ).

A molecular formula of $\mathrm{C}_{28} \mathrm{H}_{46} \mathrm{~N}_{2} \mathrm{O}$ was determined from the HRESIMS data for terminamine $\mathrm{N}$ (4). The ${ }^{1} \mathrm{H}$ - and ${ }^{13} \mathrm{C}-\mathrm{NMR}$ spectroscopic data of 4 were similar to those of 3 , except for the presence of a $\mathrm{C}=\mathrm{C}$ bond (Table 2). Thus, 4 was deduced to be the 5,6-dehydro derivative of 3. In the HMBC spectrum, the correlations from Me-19 $\left(\delta_{\mathrm{H}} 0.98\right)$ to $\mathrm{C}-5\left(\delta_{\mathrm{C}} 142.0\right)$; H-6 $\left(\delta_{\mathrm{H}} 5.35\right)$ to $C-4\left(\delta_{C} 35.2\right), C-7\left(\delta_{C} 31.9\right), C-8\left(\delta_{C} 31.7\right)$, and $C-10\left(\delta_{C} 36.9\right)$ disclosed that the $C=C$ bond was located at the C-5-C-6 position. Consequently, the structure of 4 was elucidated as $3 \beta$-dimethylamino-20 $\alpha$-senecioylamino-pregn-5-ene (Figure 1).

Terminamines $\mathrm{O}(5)$ and $\mathrm{P}(6)$ had the same molecular formula, $\mathrm{C}_{27} \mathrm{H}_{44} \mathrm{~N}_{2} \mathrm{O}$, on the basis of HRESIMS data. A comparison of the in NMR spectroscopic data with those of 4 indicated that 5 and 6 resembled 4, except for a missing N-methyl group. By comparing the 1D NMR spectra, it was considered that alkaloids 5 and $\mathbf{6}$ were stereoisomers at C-3 (Table 2). Compared with literature reports [20], together with the 3-isomers of the pregnane alkaloid derivatives [17-19], the $\beta$-orientation of the $3-\mathrm{NH}(\mathrm{Me})$ group in 5 could be assigned due to the chemical shift of $\mathrm{C}-3\left(\delta_{C} 59.5\right)$, while the upfield shift of $\mathrm{C}-3\left(\delta_{C} 54.9\right)$ leads to the assignment of a $3 \alpha-\mathrm{NH}(\mathrm{Me})$ group in 6. Further analysis of the HSQC, HMBC, and ROESY NMR data was used to establish the structure of compounds 5 and 6 as $3 \beta$-methylamino-20 $\alpha$-senecioylamino-pregn-5-ene, and $3 \alpha$-methylamino-20 $\alpha$-senecioylamino-pregn-5-ene, respectively (Figure 1).

Terminamine $\mathrm{Q}(7)$ had a molecular formula of $\mathrm{C}_{28} \mathrm{H}_{46} \mathrm{~N}_{2} \mathrm{O}_{2}$ by HRESIMS. Comparison of the ${ }^{1} \mathrm{H}$ - and ${ }^{13} \mathrm{C}$-NMR data (Table 3) showed that compound 7 has the same pregnane skeleton as epipachysamine E [3], and was thought to be the 5,6-dehydro-16-hydroxy derivative of epipachysamine E. In the HMBC spectrum, the proton signal at $\delta_{\mathrm{H}} 1.00(\mathrm{H}-19)$ correlated with the carbon signals at $\delta_{\mathrm{C}} 37.9(\mathrm{C}-1), 140.3(\mathrm{C}-5), 50.1(\mathrm{C}-9)$, and $36.6(\mathrm{C}-10)$; the signal at $\delta_{\mathrm{H}} 5.38(\mathrm{H}-6)$ correlated with the carbon signals at $\delta_{\mathrm{C}} 39.4(\mathrm{C}-4), 31.9(\mathrm{C}-7), 31.3(\mathrm{C}-8)$, and $36.6(\mathrm{C}-10)$; while the signal at $\delta_{\mathrm{H}} 0.89\left(\mathrm{H}_{3}-18\right)$ correlated with the carbon signals at $\delta_{\mathrm{C}} 41.4(\mathrm{C}-13), 53.6(\mathrm{C}-14)$, and $58.9(\mathrm{C}-17)$. In addition, the proton signal at $\delta_{\mathrm{H}} 4.36(\mathrm{H}-16)$ correlated with the signal at $\delta_{\mathrm{H}} 1.26(\mathrm{H}-17)$ in the COSY spectrum. The above observations indicated that the $\mathrm{C}=\mathrm{C}$ double bond was located at $\mathrm{C}-5-\mathrm{C}-6$, and the hydroxyl group was assigned to C-16. Furthermore, the ROESY correlations between $\mathrm{H}-16$ $\left(\delta_{\mathrm{H}}\right.$ 4.36) and $\mathrm{H}-17\left(\delta_{\mathrm{H}}\right.$ 1.26), and $\mathrm{H}-20\left(\delta_{\mathrm{H}} 2.97\right)$ and $\mathrm{H}_{3}-18\left(\delta_{\mathrm{H}} 0.89\right)$ indicated that the relative configuration of the hydroxyl group was $16 \beta$. As a result, the structure of 7 was elucidated as $20 \alpha$-dimethylamino- $16 \beta$-hydroxy-3 $\beta$-senecioylamino-pregn-5-ene.

Terminamine $\mathrm{R}(8)$ had a same molecular formula of $\mathrm{C}_{30} \mathrm{H}_{46} \mathrm{~N}_{2} \mathrm{O}_{2}$ as epipachysandrine $\mathrm{A}$ (11), as evidenced by a molecular ion peak at $m / z 467.3638[\mathrm{M}+\mathrm{H}]^{+}$from its HRESIMS spectrum. The ${ }^{1} \mathrm{H}$ - and ${ }^{13} \mathrm{C}-\mathrm{NMR}$ spectroscopic data (Table 3) of $\mathbf{8}$ were similar to those of $\mathbf{1 1}$ [20], and its structure was considered to be the 4 -isomer of $\mathbf{1 1}$. The $\alpha$-orientation of the 4 -OH group was determined by the ROESY correlation of $\mathrm{H}-4\left(\delta_{\mathrm{H}} 3.78\right)$ with $\mathrm{H}-19\left(\delta_{\mathrm{H}} 0.88\right)$. Thus, the structure of 8 was determined as $3 \beta$-benzoylamino- $4 \alpha$-hydroxy- $5 \alpha$-pregnane. 
Table 3. NMR Spectroscopic data (400 MHz, $\mathrm{CDCl}_{3}$ ) for Terminamine Q-S (7-9).

\begin{tabular}{|c|c|c|c|c|c|c|}
\hline \multirow{2}{*}{ Position } & \multicolumn{2}{|c|}{ Terminamine $Q(7)$} & \multicolumn{2}{|c|}{ Terminamine $\mathbf{R}(8)$} & \multicolumn{2}{|c|}{ Terminamine S (9) } \\
\hline & $\delta_{C}$ & $\delta_{H}(J$ in $\mathbf{H z})$ & $\delta_{C}$ & $\delta_{H}(J$ in $\mathbf{H z})$ & $\delta_{C}$ & $\delta_{H}(J$ in $\mathrm{Hz})$ \\
\hline \multirow[t]{2}{*}{1} & 37.9 & $1.84, \mathrm{~m}$ & 32.8 & $1.60, \mathrm{~m}$ & 35.6 & $1.88, \mathrm{~m}$ \\
\hline & & $1.17, \mathrm{~m}$ & & $1.10, \mathrm{~m}$ & & $1.38, \mathrm{~m}$ \\
\hline \multirow[t]{2}{*}{2} & 29.3 & $1.87, \mathrm{~m}$ & 27.1 & $2.15, \mathrm{~m}$ & 20.6 & $1.72, \mathrm{~m}$ \\
\hline & & $1.35, \mathrm{~m}$ & & $1.89, \mathrm{~m}$ & & $1.62, \mathrm{~m}$ \\
\hline 3 & 49.3 & $3.73, \mathrm{~m}$ & 51.2 & $4.47, \mathrm{~m}$ & 65.1 & $2.15, \mathrm{~m}$ \\
\hline \multirow[t]{2}{*}{4} & 39.4 & $2.34, \mathrm{~m}$ & 71.1 & $3.78, \mathrm{~m}$ & 32.0 & $1.63, \mathrm{~m}$ \\
\hline & & $2.09, \mathrm{~m}$ & & & & \\
\hline 5 & 140.3 & - & 47.4 & $1.22, \mathrm{~m}$ & 142.3 & - \\
\hline 6 & 121.7 & $5.38, \mathrm{~m}$ & 29.7 & $1.26, \mathrm{~m}$ & 120.2 & 5.34, br d $(4.8)$ \\
\hline \multirow[t]{2}{*}{7} & 31.9 & $2.02, \mathrm{~m}$ & 31.2 & $1.78, \mathrm{~m}$ & 31.7 & $1.99, \mathrm{~m}$ \\
\hline & & $1.54, \mathrm{~m}$ & & $0.89, \mathrm{~m}$ & & \\
\hline 8 & 31.3 & $1.57, \mathrm{~m}$ & 34.5 & $1.41, \mathrm{~m}$ & 30.9 & $1.65, \mathrm{~m}$ \\
\hline 9 & 50.1 & $0.98, \mathrm{~m}$ & 54.4 & $0.77, \mathrm{~m}$ & 49.8 & $1.40, \mathrm{~m}$ \\
\hline 10 & 36.6 & - & 37.2 & - & 37.1 & - \\
\hline \multirow{2}{*}{11} & 20.7 & $1.47, \mathrm{~m}$ & 20.7 & $1.54, \mathrm{~m}$ & 20.5 & $1.72, \mathrm{~m}$ \\
\hline & & & & $1.29, \mathrm{~m}$ & & $1.61, \mathrm{~m}$ \\
\hline \multirow[t]{2}{*}{12} & 40.0 & $1.84, \mathrm{~m}$ & 39.7 & $1.90, \mathrm{~m}$ & 35.2 & $2.23, \mathrm{~m}$ \\
\hline & & $1.13, \mathrm{~m}$ & & $1.20, \mathrm{~m}$ & & \\
\hline 13 & 41.4 & - & 42.5 & - & 43.0 & - \\
\hline 14 & 53.6 & $0.92, \mathrm{~m}$ & 56.1 & $1.08, \mathrm{~m}$ & 50.8 & $1.46, \mathrm{~m}$ \\
\hline \multirow[t]{2}{*}{15} & 34.9 & $2.18, \mathrm{~m}$ & 24.3 & $1.76, \mathrm{~m}$ & 39.5 & $2.20, \mathrm{~m}$ \\
\hline & & $1.25, \mathrm{~m}$ & & $1.25, \mathrm{~m}$ & 39.5 & $2.03, \mathrm{~m}$ \\
\hline 16 & 72.6 & $4.36, \mathrm{~m}$ & 24.9 & $1.92, \mathrm{~m}$ & 208.7 & - \\
\hline 17 & 58.9 & $1.26, \mathrm{~m}$ & 52.5 & $1.47, \mathrm{~m}$ & 148.2 & - \\
\hline 18 & 14.1 & $0.89, \mathrm{~s}$ & 12.3 & $0.69, \mathrm{~s}$ & 19.4 & $0.94, \mathrm{~s}$ \\
\hline 19 & 19.4 & $1.00, \mathrm{~s}$ & 13.0 & $0.88, \mathrm{~s}$ & 19.4 & $1.03, \mathrm{~s}$ \\
\hline 20 & 56.8 & $2.97, \mathrm{~m}$ & 64.0 & $3.21, \mathrm{~m}$ & 130.2 & $5.73, \mathrm{q}(7.2)$ \\
\hline 21 & 9.9 & $0.95, \mathrm{~d}(6.4)$ & 12.7 & $1.32, \mathrm{~d}(6.0)$ & 14.0 & $2.09, \mathrm{~d}(7.2)$ \\
\hline $\mathrm{N}(\mathrm{Me})_{2}$ & 39.9 & $2.25, \mathrm{~s}$ & 39.4 & $2.48, \mathrm{~s}$ & 41.7 & $2.31, \mathrm{~s}$ \\
\hline $\mathrm{NH}$ & - & $5.20, \mathrm{~d}(8.0)$ & - & $6.38, d(6.7)$ & & \\
\hline $2^{\prime}$ & 166.2 & - & 170 & - & & \\
\hline $3^{\prime}$ & 118.8 & $5.52, \mathrm{~s}$ & 134.4 & - & & \\
\hline $4^{\prime}$ & 150.4 & - & 127.1 & $7.80, \mathrm{~d}(7.2)$ & & \\
\hline $5^{\prime}$ & & & 128.6 & $7.46, \mathrm{~m}$ & & \\
\hline $6^{\prime}$ & & & 131.7 & $7.53, \mathrm{~m}$ & & \\
\hline $7^{\prime}$ & & & 128.6 & $7.46, \mathrm{~m}$ & & \\
\hline $8^{\prime}$ & & & 127.1 & $7.80, \mathrm{~d}(7.2)$ & & \\
\hline \multirow[t]{2}{*}{$4^{\prime}-(\mathrm{Me})_{2}$} & 19.7 & $2.15, \mathrm{~s}$ & & & & \\
\hline & 27.1 & $1.83, \mathrm{~s}$ & & & & \\
\hline
\end{tabular}

A molecular formula of $\mathrm{C}_{23} \mathrm{H}_{35} \mathrm{NO}$ was determined from the HRESIMS data $(\mathrm{m} / z$ 342.2822) for terminamine $\mathrm{S}(9)$. From the comparison of the ${ }^{1} \mathrm{H}$ - and ${ }^{13} \mathrm{C}-\mathrm{NMR}$ of 9 (Table 3) with those of terminamine $\mathrm{H}$ [8], alkaloid $\mathbf{9}$ was identified to be the 17(20)Z-derivative of $\mathbf{1 4}$ due to the upfield signal at $\mathrm{H}-20\left(\delta_{\mathrm{H}} 5.73\right.$ in $9,6.52$ in 14$)$. The $\beta$-orientation of the 3-dimethylamino group was determined as the same manner as described for the identification of alkaloids 3-6. Thus, the structure of 9 was determined as (Z)-3ß-(dimethylamino)-17(20)-pregn-5-en-16-one.

Compounds 1-17 were tested for their inhibitory effects on the chemotaxis of the breast adenocarcinoma cell line MDA-MB-231 induced by epidermal growth factor (EGF). All compounds were tested using non-cytotoxic concentrations. Compared with the positive control LY294002 $\left(\mathrm{IC}_{50}=1.18\right)$, compounds $\mathbf{1}, \mathbf{5}, \mathbf{7}, \mathbf{9}, \mathbf{1 2}$, and $\mathbf{1 7}$ presented significant anti-metastatic activities with $\mathrm{IC}_{50}$ values of $0.58,0.71,1.38,1.01,1.91$, and $0.31 \mu \mathrm{M}$, respectively (Table 4, Figure 4). 
Table 4. Inhibitory Effects of Compounds $1-\mathbf{1 7}^{\mathrm{a}}$ on the Invasion of MDA-MB-231 Cells.

\begin{tabular}{cccc}
\hline Compound & $\mathbf{I C}_{\mathbf{5 0}}{ }^{\mathbf{a}}(\boldsymbol{\mu M})$ & Compound & IC $_{\mathbf{5 0}}{ }^{\mathbf{a}}(\boldsymbol{\mu M})$ \\
\hline $\mathbf{1}$ & $0.58 \pm 0.06$ & $\mathbf{1 0}$ & $2.35 \pm 0.31$ \\
$\mathbf{2}$ & $4.65 \pm 0.82$ & $\mathbf{1 1}$ & $5.71 \pm 0.84$ \\
$\mathbf{3}$ & $3.14 \pm 0.51$ & $\mathbf{1 2}$ & $1.91 \pm 0.15$ \\
$\mathbf{4}$ & $8.12 \pm 0.75$ & $\mathbf{1 3}$ & $3.32 \pm 0.28$ \\
$\mathbf{5}$ & $0.71 \pm 0.06$ & $\mathbf{1 4}$ & $2.16 \pm 0.23$ \\
$\mathbf{6}$ & $6.47 \pm 0.54$ & $\mathbf{1 5}$ & $3.98 \pm 0.36$ \\
$\mathbf{7}$ & $1.38 \pm 0.17$ & $\mathbf{1 6}$ & $6.91 \pm 0.74$ \\
$\mathbf{8}$ & $8.62 \pm 1.03$ & $\mathbf{1 7}$ & $0.31 \pm 0.01$ \\
$\mathbf{9}$ & $1.01 \pm 0.09$ & & \\
LY294002 $^{\mathrm{b}}$ & $1.18 \pm 0.14$ & & \\
\hline
\end{tabular}

\footnotetext{
${ }^{\mathrm{a}}$ The values are means $\pm \mathrm{SD}(n=5) ;{ }^{\mathrm{b}} \mathrm{LY} 294002$ as a positive reagent.
}

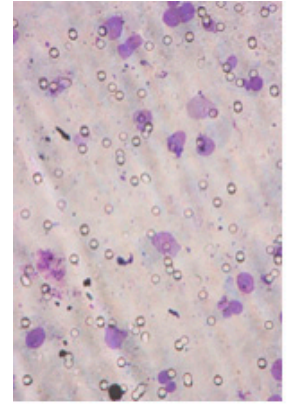

negtive control

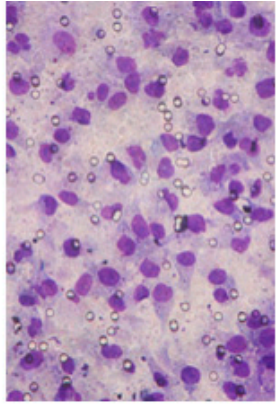

positive control

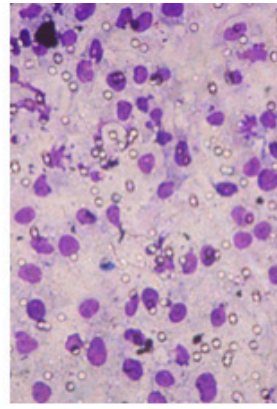

$0.1 \mu \mathrm{M}$

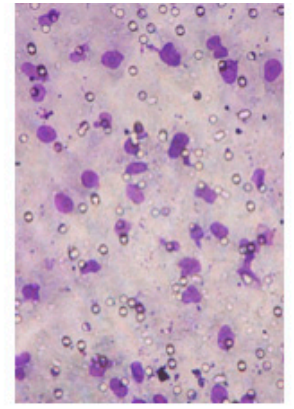

$1 \mu \mathrm{M}$

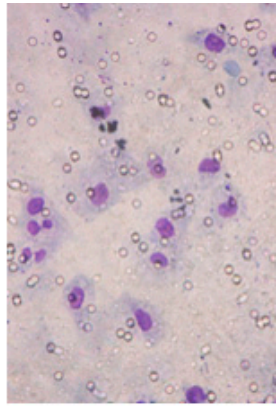

$5 \mu \mathrm{M}$

Figure 4. Anti-invasive effect of compound 1 on MDA-MB-231 cells by chemotaxis assay.

Since the methylamino or dimethylamino groups are common moieties among the active pregnane alkaloids, these substituted groups are necessary for the activity of these compounds. In addition, Z-configuration of C-17(20) could improve anti-metastatic activity compared with isomers 9, 12-16.

\section{Materials and Methods}

\subsection{General}

Optical rotation was measured with a Jasco P-2000 polarimeter (Tokyo, Japan). UV spectra were recorded in methanol on a Hitachi U-3310 UV-vis spectrophotometer (Tokyo, Japan). IR spectra were acquired using a Nicolet 380 FT-IR spectrophotometer (Waltham, MA, USA). The NMR spectra were obtained using a Bruker AVANCE III 400 instrument ( $400 \mathrm{MHz}$ for ${ }^{1} \mathrm{H}-\mathrm{NMR}$ and $100 \mathrm{MHz}$ for ${ }^{13} \mathrm{C}-\mathrm{NMR}$; Bruker Biospin AG, Fällanden, Switzerland) using TMS as an internal standard. ${ }^{1} \mathrm{H}-{ }^{1} \mathrm{H}$ COSY, HSQC, HMBC, and ROESY NMR experiments were also performed on the Bruker AVANCE III 400 instrument, using standard pulse sequences. The high-resolution mass spectra were recorded on a Varian $7.0 \mathrm{~T}$ ESI-MS (Palo Alto, CA, USA). HPLC was performed using a JASCO Gulliver Series (Tokyo, Japan) with PU-2089 pump, RI-2031, and UV-2075 detector. Semi-preparative HPLC column chromatography was carried out on YMC-Pack Polymer-C18 (6 $\mu \mathrm{m}, 10 \mathrm{~mm} \times 200 \mathrm{~mm}$ ), YMC-pack SIL-06 (YMC Co., Ltd., Kyoto, Japan). Open column chromatography was performed using silica gel (Qingdao Haiyang Chemical Co., Ltd., Qingdao, China). The chemotaxis chambers and membranes were purchased from Neuroprobe (Gaithersburg, MD, USA) and human EGF was obtained from Peprotech (Rocky Hill, NJ, USA). 


\subsection{Plant Materials}

Entire plants of Pachysandra terminalis were collected in April 2011 from Hefeng, Hubei Province, China. The plants were identified by D.R. Wan (School of Life Sciences, South Central University for Nationalities, Wuhan, Hubei Province, China) and a voucher specimen (D20110903) was deposited at the School of Pharmacy, Tianjin Medical University, Tianjin, China.

\subsection{Extraction and Isolation}

The dried plant material $(7.6 \mathrm{~kg}$ ) was extracted with 75\% ethanol (40 $\mathrm{L} \times 3,6 \mathrm{~h}$ each time) under reflux. The resultant extract was concentrated in vacuo to a gummy residue (1750 g), suspended in water, and partitioned with petroleum ether to defat. The water-soluble fraction was adjusted to pH 1 with $2 \% \mathrm{HCl}$ and then centrifuged under $5400 \mathrm{~g}$ for $10 \mathrm{~min}$. The acid-soluble fraction was alkalinized to $\mathrm{pH} 11$ with $\mathrm{NH}_{3} \cdot \mathrm{H}_{2} \mathrm{O}$ followed by exhaustive extraction with EtOAc. The EtOAc extract (32.0 g) was chromatographed on a silica gel column (300-400 mesh, $10 \times 120 \mathrm{~cm}, 1000 \mathrm{~g})$ and eluted using a solvent gradient system (petroleum ether-EtOAc-Et ${ }_{2} \mathrm{NH}, 20: 1: 1,20: 1.2: 1,20: 2: 1$, 20:3.5:1, 20:5:1, 20:10:1, v/v/v) to produce eight fractions $(\mathrm{A}-\mathrm{H})$ on the basis of TLC analysis. Fraction $\mathrm{B}$ (1.59 g) was separated by semi-preparative HPLC (polymer C-18, $\mathrm{MeOH}-\mathrm{H}_{2} \mathrm{O}-\mathrm{Et}_{2} \mathrm{NH}, 50: 50: 1.5$, $v / v / v)$ to produce seven fractions $\left(\mathrm{B}_{1}-\mathrm{B}_{7}\right)$. Fraction $\mathrm{B}_{2}(22.0 \mathrm{mg})$ was purified by semi-preparative HPLC (polymer C-18) using $\mathrm{MeOH}-\mathrm{H}_{2} \mathrm{O}-\mathrm{Et}_{2} \mathrm{NH}(50: 50: 1.5, v / v / v)$ as mobile phase to give 5 (9.4 $\left.\mathrm{mg}\right)$. Fraction $\mathrm{B}_{4}(305.1 \mathrm{mg})$ provided $8(11.9 \mathrm{mg})$ and $11(16.2 \mathrm{mg})$ after purification over semi-preparative HPLC (polymer C-18, MeOH- $\left.\mathrm{H}_{2} \mathrm{O}-\mathrm{Et}_{2} \mathrm{NH}, 80: 20: 1.5, v / v / v\right)$. Fraction D (1.3 g) was applied to a silica gel column with mixtures of petroleum ether-EtOAc-Et ${ }_{2} \mathrm{NH}(20: 1.5: 1,20: 2: 1,20: 2.5: 1,20: 4: 1, v / v / v)$ as the eluent to yield 10 fractions $\left(\mathrm{D}_{1}-\mathrm{D}_{10}\right)$. Alkaloid $6(21.6 \mathrm{mg})$ was obtained from fraction $\mathrm{D}_{7}$ $\left(68.3 \mathrm{mg}\right.$ ) separated on semi-prep. HPLC (polymer C-18) with the mobile phase of $\mathrm{MeOH}-\mathrm{H}_{2} \mathrm{O}-\mathrm{Et}_{2} \mathrm{NH}$ $(80: 20: 1.5, v / v / v)$. Alkaloids $1(67.4 \mathrm{mg})$ and $17(5.0 \mathrm{mg})$ were obtained by a silica gel column using a stepwise gradient-elution with mixtures of petroleum ether-EtOAc-Et ${ }_{2} \mathrm{NH}$ (from 20:0.5:1, to 20:1.5:1, $v / v / v)$ from $\mathrm{D}_{3}(305.2 \mathrm{mg})$ and $\mathrm{D}_{5}(88.4 \mathrm{mg})$, respectively. Fraction $\mathrm{E}(1.53 \mathrm{~g})$ was chromatographed on semi-preparative HPLC (SIL, petroleum ether-EtOAc-Et $\left.{ }_{2} \mathrm{NH}, 20: 10: 1\right)$ to produce 2 (3.0 mg), $10(47.2 \mathrm{mg})$, and 11 fractions $\left(\mathrm{E}_{1}-\mathrm{E}_{11}\right)$. Fraction $\mathrm{E}_{8}(325.6 \mathrm{mg})$ was subjected to semi-preparative HPLC (SIL) and eluted with petroleum ether-EtOAc-Et ${ }_{2} \mathrm{NH}$ (20:10:1) to obtain 9 (13.5 $\left.\mathrm{mg}\right), \mathbf{1 3}$ (36.3 mg), $14(28.7 \mathrm{mg})$, and $16(8.3 \mathrm{mg})$. Fraction G (1.76 g) was chromatographed by semi-preparative HPLC (SIL, petroleum ether-EtOAc-Et $\left.{ }_{2} \mathrm{NH}, 40: 60: 5\right)$ to obtain 7 (352.6 $\mathrm{mg}$ ) and nine fractions $\left(\mathrm{G}_{1}-\mathrm{G}_{9}\right)$. Compound 4 (2.0 mg) was obtained from fraction $\mathrm{G}_{7}(90.2 \mathrm{mg})$ by semi-preparative HPLC (SIL) with petroleum ether-EtOAc-Et ${ }_{2} \mathrm{NH}$ (20:10:1). Using the same method, 3 (10.3 $\left.\mathrm{mg}\right), \mathbf{1 2}(17.8 \mathrm{mg})$, and 15 (13.1 mg) were separated from G9 $(175.9 \mathrm{mg})$.

Terminamine $\mathrm{K}(\mathbf{1})$. Yellow oil; $[\alpha]_{\mathrm{D}}^{20}-36.3$ (c 1.13, $\left.\mathrm{CHCl}_{3}\right)$; IR (KBr) $v_{\max }: 3362,2963,2873,1750,1461$, $1371 \mathrm{~cm}^{-1}$; For ${ }^{1} \mathrm{H}-\left(\mathrm{CDCl}_{3}, 400 \mathrm{MHz}\right)$ and ${ }^{13} \mathrm{C}-\mathrm{NMR}\left(\mathrm{CDCl}_{3}, 100 \mathrm{MHz}\right)$ spectroscopic data, see Table 1; HRESIMS: $m / z 675.4617[\mathrm{M}+\mathrm{H}]^{+}$(calcd for $\mathrm{C}_{38} \mathrm{H}_{63} \mathrm{~N}_{2} \mathrm{O}_{8}, 675.4584$ ). For details of the NMR spectrum, please see the Supplementary Materials Figures S1-S6.

Terminamine L (2). White powder; $[\alpha]_{\mathrm{D}}^{20}+52.4$ (c 0.21, $\left.\mathrm{CHCl}_{3}\right)$; IR (KBr) v $v_{\text {max }}: 3388,2934,1736$, $1385 \mathrm{~cm}^{-1}$; For ${ }^{1} \mathrm{H}-\left(\mathrm{CDCl}_{3}, 400 \mathrm{MHz}\right)$ and ${ }^{13} \mathrm{C}-\mathrm{NMR}\left(\mathrm{CDCl}_{3}, 100 \mathrm{MHz}\right)$ spectroscopic data, see Table 1; HRESIMS: $m / z 455.3631[\mathrm{M}+\mathrm{H}]^{+}$(calcd for $\mathrm{C}_{29} \mathrm{H}_{47} \mathrm{~N}_{2} \mathrm{O}_{2}, 455.3638$ ). For details of the NMR spectrum, please see the Supplementary Materials Figures S7-S12.

Terminamine $\mathrm{M}$ (3). White powder; $[\alpha]_{\mathrm{D}}^{20}+21.4$ (c $\left.0.14, \mathrm{CHCl}_{3}\right) ; \mathrm{UV}(\mathrm{MeOH}) \lambda_{\max }(\log \varepsilon)$ 218 (3.32) nm; IR (KBr) $v_{\text {max }}: 3305,2930,2866,2772,1631,1533 \mathrm{~cm}^{-1}$;For ${ }^{1} \mathrm{H}-\left(\mathrm{CDCl}_{3}, 400 \mathrm{MHz}\right)$ and ${ }^{13} \mathrm{C}-\mathrm{NMR}\left(\mathrm{CDCl}_{3}, 100 \mathrm{MHz}\right)$ spectroscopic data, see Table 2; HRESIMS: $m / z 429.3846[\mathrm{M}+\mathrm{H}]^{+}$ (calcd for $\mathrm{C}_{28} \mathrm{H}_{49} \mathrm{~N}_{2} \mathrm{O}, 429.3845$ ). For details of the NMR spectrum, please see the Supplementary Materials Figures S13-S18. 
Terminamine $\mathrm{N}$ (4). Yellow oil; $[\alpha]_{\mathrm{D}}^{20}-36.4\left(\right.$ c $\left.0.22, \mathrm{CHCl}_{3}\right)$; UV (MeOH) $\lambda_{\max }(\log \varepsilon) 214$ (3.46) $\mathrm{nm}$; IR (KBr) $v_{\max }: 2967,2931,2868,2775,1668,1628 \mathrm{~cm}^{-1}$; For ${ }^{1} \mathrm{H}-\left(\mathrm{CDCl}_{3}, 400 \mathrm{MHz}\right)$ and ${ }^{13} \mathrm{C}$-NMR $\left(\mathrm{CDCl}_{3}, 100 \mathrm{MHz}\right)$ spectroscopic data, see Table 2; HRESIMS: $m / z 427.3700[\mathrm{M}+\mathrm{H}]^{+}$ (calcd for $\mathrm{C}_{28} \mathrm{H}_{47} \mathrm{~N}_{2} \mathrm{O}, 427.3688$ ). For details of the NMR spectrum, please see the Supplementary Materials Figures S19-S24.

Terminamine O (5). Yellow powder; $[\alpha]_{\mathrm{D}}^{20}-36.2\left(\right.$ c 0.58, $\left.\mathrm{CHCl}_{3}\right)$; UV $(\mathrm{MeOH}) \lambda_{\max }(\log \varepsilon) 216$ (3.55) nm; IR (KBr) $v_{\max }: 3296,2934,2869,2788,1718,1668,1630,1535,1452,1378,1261,1178 \mathrm{~cm}^{-1}$; For ${ }^{1} \mathrm{H}-$ $\left(\mathrm{CDCl}_{3}, 400 \mathrm{MHz}\right)$ and ${ }^{13} \mathrm{C}-\mathrm{NMR}\left(\mathrm{CDCl}_{3}, 100 \mathrm{MHz}\right)$ spectroscopic data, see Table 2; HRESIMS: $m / z 413.3517[\mathrm{M}+\mathrm{H}]^{+}$(calcd for $\mathrm{C}_{27} \mathrm{H}_{45} \mathrm{~N}_{2} \mathrm{O}, 413.3532$ ). For details of the NMR spectrum, please see the Supplementary Materials Figures S25-S30.

Terminamine $\mathrm{P}(6)$. Yellow powder; $[\alpha]_{\mathrm{D}}^{20}-57.1\left(c 1.05, \mathrm{CHCl}_{3}\right) ; \mathrm{UV}(\mathrm{MeOH}) \lambda_{\max }(\log \varepsilon) 215(3.64) \mathrm{nm}$; IR (KBr) $v_{\max }: 3295,2955,2925,2853,1461,1377 \mathrm{~cm}^{-1}$; For ${ }^{1} \mathrm{H}-\left(\mathrm{CDCl}_{3}, 400 \mathrm{MHz}\right)$ and ${ }^{13} \mathrm{C}-\mathrm{NMR}\left(\mathrm{CDCl}_{3}\right.$, $100 \mathrm{MHz}$ ) spectroscopic data, see Table 2; HRESIMS: $m / z 413.3549[\mathrm{M}+\mathrm{H}]^{+}$(calcd for $\mathrm{C}_{27} \mathrm{H}_{45} \mathrm{~N}_{2} \mathrm{O}$, 413.3532). For details of the NMR spectrum, please see the Supplementary Materials Figures S31-S36.

Terminamine Q (7). Yellow oil; $[\alpha]_{\mathrm{D}}^{20}-46.7$ (c 0.30, $\left.\mathrm{CHCl}_{3}\right)$; UV (MeOH) $\lambda_{\max }(\log \varepsilon) 240$ (3.72) $\mathrm{nm}$; IR (KBr) $v_{\max }: 3272,2937,2870,1741,1629,1447,1253 \mathrm{~cm}^{-1}$; For ${ }^{1} \mathrm{H}-\left(\mathrm{CDCl}_{3}, 400 \mathrm{MHz}\right)$ and ${ }^{13} \mathrm{C}-\mathrm{NMR}\left(\mathrm{CDCl}_{3}, 100 \mathrm{MHz}\right)$ spectroscopic data, see Table 3; HRESIMS: $m / z 443.3661[\mathrm{M}+\mathrm{H}]^{+}$ (calcd for $\mathrm{C}_{28} \mathrm{H}_{47} \mathrm{~N}_{2} \mathrm{O}_{2}$, 443.3638). For details of the NMR spectrum, please see the Supplementary Materials Figures S37-S42.

Terminamine R (8). Colorless oil; $[\alpha]_{\mathrm{D}}^{20}+27.8\left(\right.$ c 0.18, $\left.\mathrm{CHCl}_{3}\right)$; UV (MeOH) $\lambda_{\max }(\log \varepsilon) 220$ (3.55) nm; IR (KBr) v $v_{\max }: 3339,2930,1649,1524,1471,1383 \mathrm{~cm}^{-1}$; For ${ }^{1} \mathrm{H}-\left(\mathrm{CDCl}_{3}, 400 \mathrm{MHz}\right)$ and ${ }^{13} \mathrm{C}-\mathrm{NMR}\left(\mathrm{CDCl}_{3}, 100 \mathrm{MHz}\right)$ spectroscopic data, see Table 3; HRESIMS: $m / z 467.3638[\mathrm{M}+\mathrm{H}]^{+}$ (calcd for $\mathrm{C}_{30} \mathrm{H}_{47} \mathrm{~N}_{2} \mathrm{O}_{2}, 467.3638$ ). For details of the NMR spectrum, please see the Supplementary Materials Figures S43-S48.

Terminamine S (9). Yellow amorphous powder; $[\alpha]_{\mathrm{D}}^{20}-38.7\left(c 0.31, \mathrm{CHCl}_{3}\right) ; \mathrm{UV}(\mathrm{MeOH}) \lambda_{\max }(\log \varepsilon)$ 240 (2.66) nm; IR (KBr) $v_{\max }: 2969,2933,2853,2774,1711,1458 \mathrm{~cm}^{-1}$; For ${ }^{1} \mathrm{H}-\left(\mathrm{CDCl}_{3}, 400 \mathrm{MHz}\right)$ and ${ }^{13} \mathrm{C}-\mathrm{NMR}\left(\mathrm{CDCl}_{3}, 100 \mathrm{MHz}\right)$ spectroscopic data, see Table 3; HRESIMS: $m / z 342.2822[\mathrm{M}+\mathrm{H}]^{+}$ (calcd for $\mathrm{C}_{23} \mathrm{H}_{36} \mathrm{NO}, 342.2797$ ). For details of the NMR spectrum, please see the Supplementary Materials Figures S49-S54.

\subsection{Chemotaxis Assay}

The chemotaxis invasion assay was performed as previously described [21], using non-toxic concentrations of each compound, at which the inhibition rate on breast cancer cell growth was below $20 \%$. MDA-MB-231 cells were pretreated with the alkaloids at the indicated concentrations for $24 \mathrm{~h}$ at $37^{\circ} \mathrm{C}$ in six-well cell culture plates, then resuspended in binding medium [RPMI 1640 (Roswell Park Memorial Institute, Biological Industries, Kibbutz Beit Haemek, Israel), containing 0.1\% bovine serum albumin (BSA) and $25 \mathrm{mM}$ 4-2-hydroxyethyl-1-piperazineethanesulfonic acid] at a density of $0.5 \times 10^{6}$ cells $/ \mathrm{mL}$ and placed into the upper chamber $(50 \mu \mathrm{L} /$ well). A chemoattractant (EGF; $1 \mathrm{ng} / \mathrm{mL}$, $30 \mu \mathrm{L} /$ well) was loaded into the lower chemotaxis chamber. The 8- $\mu \mathrm{m}$ filter membranes (Neuroprobe), which had been pretreated with $0.001 \%$ fibronectin in serum-free medium at $4{ }^{\circ} \mathrm{C}$ overnight and air-dried, were inserted between the upper and lower chambers. The cells were incubated at $37^{\circ} \mathrm{C}$ in $5 \% \mathrm{CO}_{2}$ for $3.5 \mathrm{~h}$; then the whole chemotaxis chamber was inverted and the lower chamber was removed. The filter membranes were held using two small clamps and the upper side of the membrane was scraped lightly three to five times with rinsing between scrapes. The membrane was then fixed and stained with a three-step stain set (Richard-Allan Scientific, Kalamazoo, MI, USA, recorder No.: 3300). The number of migrating cells in three separate fields was counted by light microscopy at $400 \times$. Cells of sample group were pretreated with alkaloids and were induced with EGF. Positive control 
cells got EGF induction but without alkaloids pretreatment. Negative control cells got no alkaloid pretreatment or EGF induction. The inhibitory ratio (IR) was calculated as follows:

$\mathrm{IR} \%=(1-$ number of invasive cells of sample group/number of invasive cells of positive control group) $\times 100 \%$

The potencies of the products were expressed as the median inhibitory concentration $\left(\mathrm{IC}_{50}\right)$ values. LY294002 (BioSource International, Camarillo, CA, USA) was used as a positive reagent for this assay $[22,23]$.

\section{Conclusions}

In summary, this work described the isolation and structure identification of nine new (1-9) and eight known (10-17) pregnane alkaloids from the whole plant of Pachysandra terminalis. Alkaloids $\mathbf{1}$ $5,7,9,12$, and 17 presented significant anti-metastasis activities compared with the positive reagent, LY294002. In addition, the methylamino or dimethylamino groups are necessary for the activity of these compounds, and Z-configuration of C-17(20) could improve the anti-metastatic activity.

Supplementary Materials: Supplementary materials can be accessed at: http://www.mdpi.com/1420-3049/21/ $10 / 1283 / \mathrm{s} 1$.

Acknowledgments: This work was supported by the National Natural Science Foundation of China (NSFC) [grant number 81072540], and Tianjin Higher Education Science and Technology Development Project [grant number 20130105].

Author Contributions: Hong-Quan Duan conceived and designed the experiments; Xiang-Yu Li, Miao Jia, Mei-Na Jin, and Chuan Zhao performed the experiments; Yang Yu and Nan Qin contributed reagents/materials/analysis tools; Chuan Zhao wrote the paper.

Conflicts of Interest: The authors of the present manuscript have declared that no competing interests exist.

\section{References}

1. Rahman, A.; Choudhary, M.I. Chapter 2 Chemistry and Biology of Steroidal Alkaloids. In The Alkaloids: Chemistry and Biology; Cordell, G.A., Ed.; Academic Press: London, UK, 1998; Volume 50, pp. 61-108.

2. Ata, A.; Andersh, B.J. Chapter 3 Buxus Steroidal Alkaloids: Chemistry and Biology. In The Alkaloids: Chemistry and Biology; Cordell, G.A., Ed.; Academic Press: London, UK, 2008; Volume 66, pp. 191-213.

3. Funayama, S.; Noshita, T.; Shinoda, K.; Haga, N.; Nozoe, S.; Hayashi, M.; Komiyama, K. Cytotoxic alkaloids of Pachysandra terminalis. Biol. Pharm. Bull. 2000, 23, 262-264. [CrossRef] [PubMed]

4. Maeda, H.; Watanabe, K.; Watanabe, H.; Shimizu, M.; Kikuchi, T. Effects on gastric acid secretion of a steroidal alkaloid, epipachysamine-A, extracted from Pachysandra terminalis Sieb. et Zucc. J. Pharm. Dyn. 1984, 7 , 263-267. [CrossRef]

5. Osori, E.J.; Robledo, S.M.; Bastida, J. Chapter 2 Alkaloids with Antiprotozoal Activity. In The Alkaloids: Chemistry and Biology; Cordell, G.A., Ed.; Academic Press: London, UK, 2008; Volume 66, pp. 113-190.

6. Sun, Y.; Yan, Y.X.; Chen, J.C.; Lu, L.; Zhang, X.M.; Li, Y.; Qiu, M.H. Pregnane alkaloids from Pachysandra axillaries. Steroids 2010, 75, 818-824. [CrossRef] [PubMed]

7. Zhai, H.Y.; Zhao, C.; Zhang, N.; Jin, M.N.; Tang, S.A.; Qin, N.; Kong, D.X.; Duan, H.Q. Alkaloids from Pachysandra terminalis inhibit breast cancer invasion and have potential for the development of anti-metastasis therapeutic agents. J. Nat. Prod. 2012, 75, 1305-1311. [CrossRef] [PubMed]

8. Zhao, C.; Gan, C.C.; Jin, M.N.; Tang, S.A.; Qin, N.; Duan, H.Q. Antitumor metastasis pregnane alkaloids form Pachysandra terminalis. J. Asian Nat. Prod. Res. 2014, 16, 440-446. [CrossRef] [PubMed]

9. Zhang, P.Z.; Wang, F.; Yang, L.J.; Zhang, G.L. Pregnane alkaloids from Sarcococca hookeriana var. digyna. Fitoterapia 2013, 89, 143-148. [CrossRef] [PubMed]

10. Kikuchi, T.; Uyeo, S. Pachysandra alkaloids. III. Structures of pachysandrin B, -C, and -D. Chem. Pharm. Bull. 1967, 15, 207-213. [CrossRef]

11. Kikuchi, T.; Uyeo, S.; Nishinaga, T. Studies on the alkaloids of Pachysandra terminals Sieb. et Zucc. (8): Structure of epipachysandrine-A. Tetrahedron Lett. 1966, 7, 1749-1752. [CrossRef] 
12. Sanchez, V.; Ahond, A.; Guihem, J.; Poupat, C.; Potier, P. Alcaloides des feuilles de Didymeles madagascariensis Willd., des feuilles et des ecorces de racines de Didymeles perrieri Leandri (Didymelacees). Bull. Soc. Chim. Fr. 1987, 5, 877-884.

13. Atta-ur-Rahman; Choudhary, M.I.; Khan, M.R.; Iqbal, M.Z. Three new steroidal amines from Sarcococca saligna. Nat. Prod. Lett. 1998, 11, 81-91. [CrossRef]

14. Chiu, M.H.; Nie, R.L.; Li, Z.R.; Zhou, J. Isospiropachysine, a steroidal alkaloid from Pachysandra axillaries. Phytochemistry 1990, 29, 3927-3930.

15. Yan, Y.X.; Sun, Y.; Chen, J.C.; Wang, Y.Y.; Li, Y.; Qiu, M.H. Cytotoxic steroids from Sarcococca saligna. Planta Med. 2011, 77, 1725-1729. [CrossRef] [PubMed]

16. Sen, S.E.; Roach, S.L. A convenient two-step procedure for the synthesis of substituted allylic amines from allylic alcohols. Synthesis 1995, 7, 756-758. [CrossRef]

17. Liu, J.; Ma, S.N.; Zhang, X.; Jin, M.N.; Jin, M.H.; Kong, D.X.; Qin, N.; Duan, H.Q. Synthesis and antimetastatic effect of E-salignone. Chem. Nat. Compd. 2014, 50, 697-701. [CrossRef]

18. Qin, N.; Jia, M.; Wu, X.R.; Shou, X.A.; Liu, Q.; Gan, C.C.; Jin, M.N.; Yu, Y.; Duan, H.Q. Synthesis and anti-metastatic effects of pregn-17(20)-2n-3-amine-derivatives. Eur. J. Med. Chem. 2016, 124, 490-499. [CrossRef] [PubMed]

19. Wang, H.L.; Qin, N.; Liu, J.; Jin, M.N.; Zhang, X.; Jin, M.H.; Kong, D.X.; Jiang, S.D.; Duan, H.Q. Synthesis and antimetastatic effects of $E$-salignone amide derivatives. Drug Dev. Res. 2014, 75, 76-87. [CrossRef] [PubMed]

20. Qiu, M.H.; Wang, D.Z.; Nie, R.L. Study on ${ }^{13}$ C-NMR spectroscopy of Pachysandra alkaloids. Chin. J. Magn. Reson. 1995, 12, 155-165.

21. Wan, W.Z.; Zou, H.X.; Sun, R.H.; Liu, Y.; Wang, J.N.; Ma, D.L.; Zhang, N. Investigate the role of PTEN in chemotaxis of human breast cancer cells. Cell Signal. 2007, 19, 2227-2236. [CrossRef] [PubMed]

22. Sun, R.H.; Gao, P.; Chen, L.; Ma, D.L.; Wang, J.M.; Oppenheim, J.J.; Zhang, N. Protein kinase C zeta is required for epidermal growth factor-induced chemotaxis of human breast cancer cells. Cancer Res. 2005, 65, 1433-1441. [CrossRef] [PubMed]

23. Vlahos, C.J.; Matter, W.F.; Hui, K.Y.; Brown, R.F. A specific inhibitor of phosphatidylinositol 3-kinase, 2-(4-morpholinyl)-8-phenyl-4H-1-benzopyran-4-one (LY294002). Biol. Chem. 1994, 7, 5241-5248.

Sample Availability: Not available.

(C) 2016 by the authors; licensee MDPI, Basel, Switzerland. This article is an open access article distributed under the terms and conditions of the Creative Commons Attribution (CC-BY) license (http://creativecommons.org/licenses/by/4.0/). 